Biol. Proced. Online 2002;4(1): 88-93.

\title{
A Sensitive Quantification of HHV-6B by Real-time PCR
}

\author{
Bodil Øster $^{1}$ and Per Höllsberg ${ }^{1 *}$ \\ ${ }^{1}$ Department of Medical Microbiology and Immunology, Bartholin Building, University of Aarhus, DK-8000 Aarhus, Denmark. \\ *Corresponding author: Per Höllsberg, M.D., Department of Medical Microbiology and Immunology, Bartholin Building, \\ University of Aarhus, DK-8000 Aarhus C, Denmark. Phone: +45 8942 1772. Fax: +45 8619 6128. E-mail: ph@microbiology.au.dk
}

Submitted: September 4, 2002; Revised: November 12, 2002; Accepted: November 12, 2002; Published: December 9, 2002

Indexing terms: HHV-6B; PCR; mRNA.

\begin{abstract}
Human herpesvirus (HHV)-6B is a pathogen causing latent infection in virtually all humans. Nevertheless, the interaction of HHV-6B with its host cells is poorly understood. Although HHV-6B is approximately $90 \%$ homologous to HHV-6A, it expresses certain B-specific genes. In order to quantify the amount of expressed viral mRNA we have developed a method using real-time PCR on a LightCycler instrument. Here we describe an assay for the detection of the HHV-6B B6 mRNA, but our approach can easily be extended to involve other mRNAs. This method is useful during the study of HHV-6B biology and offers reliable and reproducible, quantitative detection of viral mRNA below the attomol range.
\end{abstract}

\section{INTRODUCTION}

In 1986, a novel virus was isolated from six immunocompromised patients by Salahuddin and co-workers and was denoted Human B-lymphotropic virus (HBLV) due to their capability to infect B cells (1). HBLV was shown to possess a double-stranded DNA genome consisting of more than $110 \mathrm{kbp}$ and was identified as a member of the herpesvirus family (2). Later the virus was shown to have a broader host cell range with $\mathrm{T}$ cells as a major target and was renamed human herpesvirus 6 (HHV-6) $(3,4)$. Based on differences in restriction enzyme cleavage patterns and different reactivity with monoclonal antibodies between different isolates, HHV-6 was divided into two subgroups, HHV-6A and HHV-6B. These viruses are two closely related betaherpesviruses with an overall nucleotide identity of $90 \%$ $(5,6)$. Whereas more than $90 \%$ become seropositive to HHV$6 \mathrm{~B}$ in early childhood, the epidemiology of HHV-6A is less well characterized. Both HHV-6A and $-6 \mathrm{~B}$ infects $\mathrm{T}$ cells and monocytes in vivo $(7,8)$, but the viral gene expression from infected cells is only partially described. Since HHV-6A and 6B may give rise to different types of infections and clinical outcomes, it is of interest to develop sensitive methods to distinguish between these viruses.

PCR amplifications of reverse-transcribed RNA is a sensitive method for analyzing viral gene expression. However, conventional PCR is not quantitative, since the number of amplification cycles it takes before the amplified product reaches a plateau is not investigated. This contains the potential pitfall that samples with different amounts of template have reached the same plateau after 30 cycles, i.e., the same amount of amplified product, although the kinetics of the amplifications have been quite different. To avoid these problems, real-time PCR has been developed in order to monitor the amount of amplified product in each cycle.

Recently, the genomes of HHV-6A and HHV-6B have been sequenced $(5,6)$. Further studies have predicted 97 unique genes in HHV-6B, 88 of which have counterparts in HHV-6A (5). However, HHV-6A and HHV-6B each comprise nine genes, which are completely unique for each virus. The nine HHV-6B specific genes, designated B1-B9, provide nine obvious potential markers for HHV-6B infection.

Using real-time PCR, we have recently characterized the expression patterns of approximately one third of the HHV-6B encoded genes with emphasis on their temporal expression (9). This analysis identified the expression of a number of previously predicted B-specific genes $(5,9)$. To further quantify the amount of expressed mRNA we have developed a method using real-time PCR on a LightCycler instrument. This method is useful during the study of HHV-6B biology and offers reliable and reproducible detection of even small amounts of viral mRNA. Here the B6 transcript has been detected by realtime PCR at different time points after infection.

(C) 2002. Biological Procedures Online. Published in Biological Procedures Online under license from the author(s). Copying, printing, redistribution and storage permitted.

Biological Procedures Online • Vol. 4 No. 1 • December 9, $2002 \bullet$ www.biologicalprocedures.com 


\section{MATERIALS AND METHODS}

\section{Virus, cell culture, and T-cell infection}

The T-lymphoblastic cell line Molt-3 was infected by HHV6B, strain PL1 (generated by Dr. P. Lusso). Molt-3 T cells were grown at $37^{\circ} \mathrm{C}$ and $5 \% \mathrm{CO}_{2}$ in Dulbecco's Modified Eagle Medium (DMEM) supplemented with glutamine (0.292 $\mathrm{g} / \mathrm{L}), 10 \mathrm{mM}$ HEPES, streptomycin $(0.2 \mathrm{~g} / \mathrm{L})$, penicillin $(0.2$ i.e./L), and $10 \%$ heat inactivated fetal bovine serum. Virus was collected from the supernatants of HHV-6B-infected T cells. The supernatants were cleared from cell debris by centrifugation at $4500 \times \mathrm{g}$ for 1 hour, and subsequently centrifuged at $100,000 \times \mathrm{g}$ for 1 hour. Infection was performed with $8 \times 10^{6}$ Molt- 3 cells per $\mathrm{ml}$ of 20 -fold concentrated virus supernatant.

\section{RNA purification}

Total RNA was isolated from $2 \times 10^{6} \mathrm{~T}$ cells at room temperature using High Pure RNA Isolation Kit (Roche Diagnostics Scandinavia AB, Hvidovre, Denmark). In brief, $\mathrm{T}$ cells were lysed in $4.5 \mathrm{M}$ guanidine hydrochloride, $50 \mathrm{mM}$ Tris- $\mathrm{HCl}$ and $30 \%$ Triton X-100 (w/v), pH 6.6, followed by the collection of nucleotides on a filter by high-speed centrifugation. To remove contaminating DNA, nucleotides were treated with $200 \mathrm{U}$ DNase for $15 \mathrm{~min}$ and washed once in a buffer consisting of $5 \mathrm{M}$ guanidine hydrochloride and $20 \mathrm{mM}$ Tris $\mathrm{HCl}(\mathrm{pH}$ 6.6) in ethanol, and twice in a buffer consisting of $20 \mathrm{mM} \mathrm{NaCl}$ and $2 \mathrm{mM}$ Tris- $\mathrm{HCl}(\mathrm{pH} \mathrm{7.5)}$ in ethanol. Finally, RNA was eluted in sterile, nuclease-free, doubledistilled $\mathrm{H}_{2} \mathrm{O}$ in a total volume of $60 \mu \mathrm{l}$. Total RNA concentration was determined in triplicates by absorbance measurements (GeneQuant II RNA/DNA Calculator, Pharmacia Biotech, Hørsholm, Denmark).

\section{Reverse transcription (RT)-PCR}

First-strand cDNA synthesis from $1 \mu \mathrm{g}$ of total RNA was performed using 100 pmol of $\mathrm{p}(\mathrm{dT})_{15}$ primer for cDNA synthesis (Roche, Hvidovre, Denmark) followed by a denaturation step at $65^{\circ} \mathrm{C}$ for $10 \mathrm{~min}$. The RNA was reverse transcribed using the method described by the manufacturer of the Expand Reverse Transcriptase kit for first-strand synthesis (Roche, Hvidovre, Denmark) for $45 \mathrm{~min}$ at $42^{\circ} \mathrm{C}$. In brief, $1 \times$ Expand Reverse Transcriptase buffer (first strand) was mixed with DTT in a final concentration of $10 \mathrm{mM}$, dNTP-mix, disodiumsalt solution with dATP, dCTP, dGTP, and dTTP at a final concentration of $1 \mathrm{mM}, 20 \mathrm{U}$ RNase inhibitor, and $50 \mathrm{U}$ Expand Reverse Transcriptase enzyme. The reaction was stopped at $95^{\circ} \mathrm{C}$ for 2 minutes. The cDNA was diluted to $40 \mu 1$ with double-distilled $\mathrm{H}_{2} \mathrm{O}$. To avoid sample-to-sample contamination, separate laboratories were used for RNA purification, PCR set-up and template addition.

\section{Primers and probes}

Primers and probes for PCR amplification were designed by and purchased from TIB-MOLBIOL (Berlin, Germany). The primers for the internal standard $\beta_{2}$-microglobulin were as follows: forward primer: CAA GCA GAG AAT GGA AAG TC; reverse primer: GAT GCT GCT TAC ATG TCT CG.

The forward and reverse primers for the HHV-6B specific gene B6 are shown in Fig. 1 together with the specific internal probes B6 FL and B6 LC. The B6 FL probe was labeled at its 3 '-end with the donor dye, Fluorescein (FL) and the B6 LC probe was labeled at its 5 '-end with the acceptor dye, LightCycler-Red 640 (LC Red 640).

ATGTGGTATGAGCTGACATCTGCAAAAACAAATGAAAGTCTCCCCCGGAGTACACGTA TACACCATACTCGACTGTAGACGTTTTTGTTTACTTTCAGAGGGGGCCTCATGTGCAT

$\frac{\text { B6 F }}{\text { TGTACTCCGGGGGAACCTCAAAAATGCACAATTTAGCCTATTAAGCAGCCGCGAACT }}$ B6 LC

CGTTAATAGTTACTTTGATGTTAACTCAGGTGGTGGCTTGGATGGTGTCCTAAGTATC GCAATTATCAATGAAACTACAATTGAGTCCACCACGGAACCTACCACAGGATTCATAG B6 FL B6 R

AATCGAAGCTCCTTTATTTTTTGCACTACTGAAGTTATTCTAGGTATCGGGGTAAGAA TTAGCTTCGAGGAAATAAAAAACGTGATGACTTCAATAAGATCCATAGCCCCATTATT

TAAGATGA

ATTСTACT

Fig. 1: Location of primers and probes in B6 of HHV-6B. The entire ORF of B6, strain Z29 is shown (GenBank Accession number AF157706). The region spanning the two primers has been sequenced and found $100 \%$ identical between strain Z29 and strain PL1 [9]. B6 F, forward primer; B6 LC and B6 $\mathrm{FL}$, internal probe-pair; B6 R, reverse primer.

\section{Optimization of PCR conditions}

The concentration of the probe $\mathrm{B} 6 \mathrm{LC}$ was optimized with 0.2 $\mu \mathrm{M}, 0.3 \mu \mathrm{M}$, and $0.4 \mu \mathrm{M}$. The annealing temperature was optimized with $55^{\circ}, 57^{\circ}, 60^{\circ}$, and $62^{\circ} \mathrm{C}$ and the $\mathrm{MgCl}_{2}$ concentrations with $1,2,3,4$, and $5 \mathrm{mM}$.

\section{Real-time quantitative PCR}

Real-time PCR was carried out using the LightCycler FastStart DNA Master Hybridization Probes reagent (Roche, Hvidovre, Denmark). A standard curve was created by amplifications of a synthetic oligonucleotide (DNA Technologies, Aarhus, Denmark) with the same sequence as the product amplified by B6F/B6R. For quantification, the test template used was cDNA derived from reverse transcribed RNA isolated $0 \mathrm{~h}, 1 \mathrm{~h}, 3 \mathrm{~h}, 8 \mathrm{~h}, 22 \mathrm{~h}$, and $48 \mathrm{~h}$ after infection. $\mathrm{H}_{2} \mathrm{O}$ was included as a no template control, and cDNA derived from reverse transcribed RNA isolated from uninfected Molt-3 T cells as a negative control. The oligonucleotide standard was diluted in water in ten-fold dilutions over a range spanning the sample concentrations. To minimize variation between the oligonucleotide standard curve and the samples, due to the 
presence of potential inhibitory factors in the samples, $5 \mu 1$ of cDNA from non-infected Molt-3 $\mathrm{T}$ cells was added to each standard dilution. Oligonucleotide standard and cDNA were amplified in a mixture of $5 \mu \mathrm{lDNA}$ /diluted oligonucleotide standard, $2.5 \mathrm{mM} \mathrm{MgCl} 2,0.5 \mu \mathrm{M}$ primer B6 F, $0.5 \mu \mathrm{M}$ primer B6 R, $0.2 \mu \mathrm{M}$ Probe B6 LC, $0.2 \mu \mathrm{M}$ Probe B6 FL, and $2 \mu 1$ LightCycler - FastStart DNA Master Hybridization Probes in a final volume of $20 \mu \mathrm{l}$. The PCR reaction was performed on a LightCycler instrument with 1 cycle of denaturation for $10 \mathrm{~min}$ at $95^{\circ} \mathrm{C}$ and 45 cycles of amplification at $95^{\circ}$ for $10 \mathrm{sec}, 60^{\circ} \mathrm{C}$ for $10 \mathrm{sec}$ and $72^{\circ} \mathrm{C}$ for $5 \mathrm{sec}$. Cooling to $40^{\circ} \mathrm{C}$ took $30 \mathrm{sec}$.

\section{The log phase is used for quantification}

A PCR can be divided into three phases. The first is the background phase, which lasts until the signal of the amplified product exceeds the background signal. The second is the exponential growth phase (the log phase), which finally ends in the plateau phase. The plateau phase is reached if reaction byproducts accumulate and inhibit the reaction, if product reannealing takes over and starts competing with the hybridization of the primers, or if the enzyme is heatinactivated over time and thereby becomes limiting (10). The amount of product can be determined from the log phase. In the $\log$ phase the amount of product increases logarithmically with a maximal efficiency of 2 and a minimum efficiency of 1 . The number of cycles required to produce a signal above background fluorescence can be converted to the starting concentration of the unknowns from the standard curve. The crossing point value $(\mathrm{Cp})$ is the point where the log line intersects a horizontal threshold line (discarding background fluorescence). The amount of target is the same in all samples at this point of intersection (10). The amplification course of the log phase is described by the following equation:

$$
\mathrm{T}_{\mathrm{n}}=\mathrm{T}_{0}(\mathrm{E})^{\mathrm{n}}
$$

Where $T_{n}$ is the amount of target at $n$ cycles, $T_{0}$ the initial amount of target, and $E$ the efficiency of amplification (10). If the copy number of target at the crossing point is $\mathrm{K}$, and the cycle number to obtain $\mathrm{K}$ is $\mathrm{Cp}$, then by equation 1 :

$$
\mathrm{K}=\mathrm{T}_{0}(\mathrm{E})^{\mathrm{Cp}} \quad(2) \Leftrightarrow \log \mathrm{K}=\log \mathrm{T}_{0}+\mathrm{Cp} \log \mathrm{E}
$$

$\mathrm{Cp}$ is the value measured and $\mathrm{T}_{0}$ the initial concentration of the standard determined by the investigator. Rearranging to the form $\mathrm{y}=\mathrm{ax}+\mathrm{b}$ gives:

$$
\mathrm{Cp}=-(1 / \log \mathrm{E}) \log \mathrm{T}_{0}+(\log \mathrm{K} / \log \mathrm{E})
$$

The standard curve is described by this equation with the log of the initial template copy number plotted horizontally and the cycle number at the crossing point vertically. By equation 4 :
Slope $=-1 / \log E(5) \Leftrightarrow \log E=-1 /$ Slope $(6) \Leftrightarrow E=10^{-1 / \text { Slope }}$

Where E is the efficiency and "Slope" is the slope of the standard curve. To obtain reliable results it is important to achieve equivalent PCR efficiencies for the standard curve and the samples. The sample efficiency was determined in a series of template dilutions.

\section{RESULTS AND DISCUSSION}

\section{The $\beta_{2}$-microglobulin values were highly reproducible}

The reproducibility of the method used for the initial detection of the HHV-6B-specific transcript B6 was determined in three independent but identical experiments using internal controlprimers for $\beta_{2}$-microglobulin. In each experiment, the relative amount of $\beta_{2}$-microglobulin was determined with 13 separate measurements on each cDNA from infected T cells (Fig. 2).

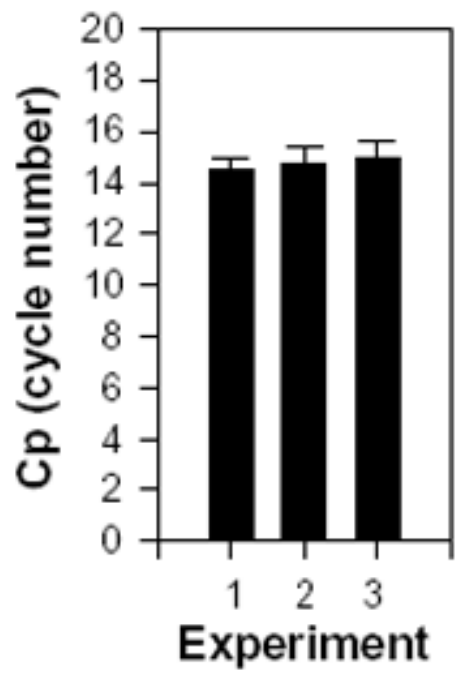

Fig. 2: Reproducibility of internal control. As an internal control, $\beta_{2}$ microglobulin was amplified in three independent but identical experiments with 13 separate measurements on each cDNA. The number of cycles (Cp) demanded to amplify the initial amount of target above background is used as a measure for the relative amount of target. The standard deviation is indicated on each bar.

The determination by real-time PCR with $\beta_{2}$-microglobulin as an internal control was highly reproducible. In addition, when comparing the amount of $\beta_{2}$-microglobulin in uninfected cells with the amount found in infected cells, no difference was observed (data not shown).

In conclusion, $\beta_{2}$-microglobulin turned out to be useful as an internal control, since the values at all times were highly reproducible, and since the cellular expression level apparently was unaffected by the HHV-6B infection. 


\section{Optimal PCR conditions}

Matrix experiments to systematically define the optimal conditions for two primers and two probes with respect to concentrations, temperatures and $\mathrm{MgCl}_{2}$ will define the best conditions for the reactions. However, such experiments are large and fairly expensive. We have had success with an approach where our primers are designed with an expected annealing temperature around $60^{\circ} \mathrm{C}$. Of notice, the concentration of $\mathrm{MgCl}_{2}$ in real-time PCR using the LightCycler technology is higher than that used in conventional PCR. The probes designed by TIB MOLBIOL (Berlin, Germany) are carefully selected to have similar characteristics. For practical purposes we chose to optimize on only one of the probes. For the quantification of B6, we found the optimal conditions to be $0.2 \mu \mathrm{M}$ probe $\mathrm{B} 6 \mathrm{LC}$, the annealing temperature $60^{\circ} \mathrm{C}$ and 4.5 $\mathrm{mM} \mathrm{MgCl}{ }_{2}$.

\section{Similar PCR efficiencies were obtained}

The efficiency is obtained by plotting the crossing point $(\mathrm{Cp})$ values against the log of the initial template concentration (Fig. 3). Sample and standard efficiencies are equal if they have the same slope. In addition, they should be constant over the concentration range studied, that is, linearity should be obtained on semi-log plots.

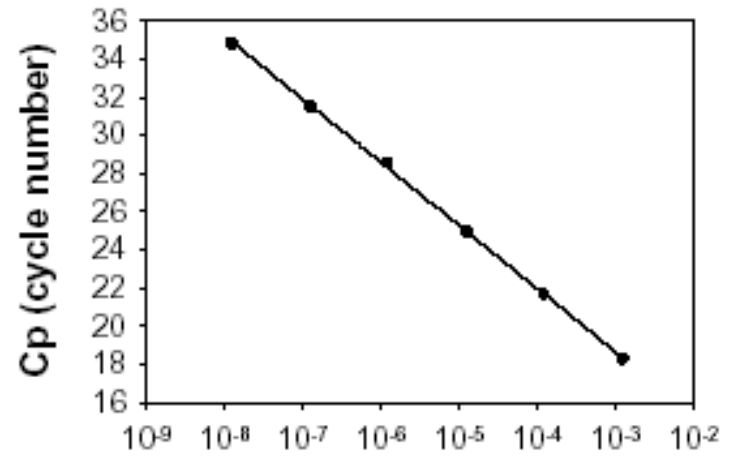

\section{Log template concentration (pmol)}

Fig. 3: PCR amplification efficiency. The crossing point $(\mathrm{Cp})$ values plotted against the $\log$ of the initial template concentrations. From the formula $E=10^{-}$ 1 Slope the efficiency is calculated to 2.0 , in that the slope of the line is -3.304 .

As shown in Fig. 3, the efficiency of the standard amplification was found to be constant over the concentration range studied. That is, linear plots were obtained with an efficiency of 2.0, indicating an exponential increase of the product. Likewise, a linear plot with a comparable efficiency was obtained in a number of sample dilutions (data not shown).

\section{Viral mRNA can be detected in attomol amounts}

In initial experiments, the relative amount of the HHV-6Bspecific transcript B6 was determined at $0 \mathrm{~h}, 1 \mathrm{~h}, 3 \mathrm{~h}, 8 \mathrm{~h}, 22 \mathrm{~h}$, and $48 \mathrm{~h}$ after infection (Fig. 4). Surprisingly transcripts could be detected as early as $1 \mathrm{~h}$ after infection. Based on further experiments (9) B6 was characterized as belonging to the group of genes expressed immediately after infection. As can be seen from Fig. 4, the increase in mRNA amount is pronounced early after infection.

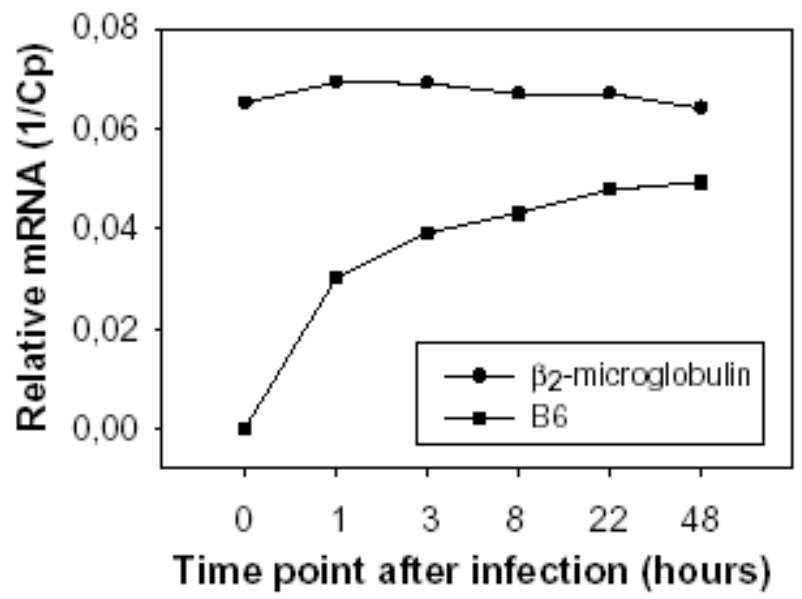

Fig. 4: Detection of B6 mRNA. The relative amount of B6 mRNA was determined at the indicated time points after infection. The amount of $\beta_{2-}$ microglobulin was constant in all test materials whereas the amount of B6 mRNA increased over time.

To make a relative quantification of the transcripts, specific probes were designed for B6 (Fig. 1) in addition to a synthetic oligonucleotide encompassing the B6 primers annealing sites. The quantification was performed in two separate experiments with separately prepared standard curves but with the same batch of samples. Concentrations were reproducibly determined below the attomol range in duplicate experiments (Table 1).

Table 1: Quantification of the amount of B6 mRNA present per ng total RNA at different time points following HHV-6B (PL1) infection of Molt-3 cells.

\begin{tabular}{lcccc}
\hline Template & B6 $\left(10^{-21}\right.$ mol/ng RNA $)$ & $\begin{array}{c}\text { Mean copy } \\
\text { number/ng } \\
\text { RNA }\end{array}$ & \\
\cline { 2 - 4 } & & & & \\
\cline { 2 - 4 } & Exp. 1 & Exp. 2 & Mean & \\
\hline Uninfected cells & 0.00 & 0.00 & 0.00 & 0 \\
cDNA 1 h & 0.19 & 0.15 & 0.17 & 106 \\
cDNA 3 h & 13.7 & 23.7 & 18.7 & 11,650 \\
cDNA 8 h & 276 & 196 & 236 & 147,028 \\
cDNA 22 h & 589 & 608 & 598 & 372,554 \\
cDNA 48 h & 696 & 568 & 632 & 393,736 \\
No template control & 0.00 & 0.00 & 0.00 & 0 \\
\hline
\end{tabular}

Thus, this method possesses the advantages of being fast, sensitive, and highly reproducible. These features may be of special interest when studying low-level HHV-6B expression in latently infected cells. In addition, it can be used for DNA quantification in different specimens, including its application 
as a novel sensitive measurement of virus titers in supernatants, an approach that would be faster and more specific than the conventional read-out of cytopathic effects in cell culture systems.

\section{ACKNOWLEDGMENTS}

We thank P. Lusso for the PL-1 strain of HHV-6B and Z. Berneman and his laboratory for cell lines and advice. This work was supported by grant 9903024 from the Danish Medical Research Council and the Novo Nordic Research Foundation.

\section{REFERENCES}

1. Salahuddin SZ, Ablashi DV, Markham PD, Josephs SF, Sturzenegger S, Kaplan $\mathrm{M}$ et al. Isolation of a new virus, HBLV, in patients with lymphoproliferative disorders. Science 1986; 234(4776):596-601.

2. Josephs SF, Salahuddin SZ, Ablashi DV, Schachter F, Wong-Staal F, Gallo RC. Genomic analysis of the human B-lymphotropic virus (HBLV). Science 1986; 234(4776):601-603.

3. Ablashi DV, Salahuddin SZ, Josephs SF, Imam F, Lusso $\mathrm{P}$, Gallo RC et al. HBLV (or HHV-6) in human cell lines. Nature 1987; 329(6136):207.

4. Lusso P, Salahuddin SZ, Ablashi DV, Gallo RC, di M, V, Markham PD. Diverse tropism of HBLV (human herpesvirus 6). Lancet 1987; 2(8561):743.

5. Dominguez G, Dambaugh TR, Stamey FR, Dewhurst S, Inoue $\mathrm{N}$, Pellett PE. Human herpesvirus 6B genome sequence: coding content and comparison with human herpesvirus 6A. J Virol 1999; 73(10):8040-8052.

6. Isegawa Y, Mukai T, Nakano K, Kagawa M, Chen J, Mori $\mathrm{Y}$ et al. Comparison of the complete DNA sequences of human herpesvirus 6 variants A and B. J Virol 1999; 73(10):8053-8063.

7. Lusso P, Malnati MS, Garzino-Demo A, Crowley RW, Long EO, Gallo RC. Infection of natural killer cells by human herpesvirus 6. Nature 1993; 362(6419):458-462.

8. Yamanishi K. Human Herpesvirus 6 and Human Herpesvirus 7. In: David M.Knipe, Peter M.Howley, Diane E.Griffin, Robert A.Lamb, Malcolm A.Martin, Bernard Roizman et al., eds. Fields Virology. Philadelphia: Lippincott Williams \& Wilkins. 2001: 2785-2801.

9. Øster B, Höllsberg P. Viral gene expression patterns in human herpesvirus 6B-infected T cells. J Virol 2002; 76(15):7578-7586.

10. Rasmussen R. Quantification on the LightCycler. In: Meuer S, Wittwer C, Nakagawara K, eds. Rapid Cycle Real-Time PCR. Springer. 2001. 


\section{PROTOCOLS}

\section{Cell culture, virus, and T-cell infection}

1. Grow Molt-3 T cells in Dulbecco's Modified Eagle Medium (DMEM) supplemented with 10\% heat inactivated fetal bovine serum, glutamine $(0.292 \mathrm{~g} / \mathrm{L}), 10 \mathrm{mM} \mathrm{HEPES}$, streptomycin $(0.2 \mathrm{~g} / \mathrm{L})$, and penicillin $(0.2 \mathrm{i} . \mathrm{e} . / \mathrm{L})$ at $0.6 \times 10^{6} \mathrm{Molt}-3$ $\mathrm{T}$ cells $/ \mathrm{ml}$.

2. Resuspend $8 \times 10^{6}$ Molt-3 T cells per ml virus (HHV-6B) supernatant.

3. Dilute the infected cells to $4 \times 10^{6}$ cells $/ \mathrm{ml}$ with supplemented DMEM.

4. Expand with fresh supplemented DMEM when needed (if the medium changes color from red to orange/dark yellow).

5. Isolate RNA at the preferred time points after infection from $2 \times 10^{6}$ infected Molt- 3 T cells using High Pure RNA Isolation Kit (Roche Diagnostics Scandinavia AB, Hvidovre Denmark) as described by the manufacturer.

6. Determine the concentration of total RNA by absorbance measurements.

\section{cDNA synthesis}

1. Mix $1 \mu \mathrm{g}$ of total RNA with $100 \mathrm{pmol}$ of $\mathrm{p}(\mathrm{dT})_{15}$ primer for cDNA synthesis (Roche, Hvidovre, Denmark).

2. Denature the RNA at $65^{\circ} \mathrm{C}$ for $10 \mathrm{~min}$. Put on ice immediately after.

3. Prepare a mixture of $1 \times$ Expand Reverse Transcriptase buffer (first strand), DTT in a final concentration of $10 \mathrm{mM}$, dNTP-mix, disodiumsalt solution with dATP, dCTP, dGTP, and dTTP at a final concentration of $1 \mathrm{mM}, 20 \mathrm{U}$ RNase inhibitor, and $50 \mathrm{U}$ Expand Reverse Transcriptase enzyme.

4. Add the nucleotide/buffer/enzyme mixture to each tube containing denatured total RNA and $\mathrm{p}(\mathrm{dT})_{15}$ primer in a final volume of $20 \mu 1$.

5. Incubate the tubes at $42^{\circ} \mathrm{C}$ for $45 \mathrm{~min}$.

6. Stop the reaction at $95^{\circ} \mathrm{C}$ for 2 minutes.

7. Put on ice and freeze at $-70^{\circ} \mathrm{C}$.

\section{Quantitative real-time PCR}

1. Optimize $\mathrm{MgCl}_{2}$ concentration, annealing temperature, and amount of target.

2. Dilute the standard (synthetic oligonucleotide or cloned fragment) in water in ten-fold dilutions in a range spanning the sample concentrations immediately before use. Keep the dilutions on ice.

3. Prepare a reaction mixture for all samples containing all ingredients (except from the template) with $2.5 \mathrm{mM} \mathrm{MgCl} 2,0.5$ $\mu \mathrm{M}$ forward primer, $0.5 \mu \mathrm{M}$ reverse primer, $0.2 \mu \mathrm{M}$ Probe LC Red, $0.2 \mu \mathrm{M}$ Probe FL, and $2 \mu 1$ LightCycler - FastStart DNA Master Hybridization Probes.

4. Mix $5 \mu \mathrm{l}$ of each cDNA/diluted oligonucleotide with $15 \mu \mathrm{l}$ reaction mixture immediately before analysis.

5. Perform the PCR reation on a LightCycler instrument with 1 cycle of denaturation for $10 \mathrm{~min}$ at $95^{\circ} \mathrm{C}$ and 45 cycles of amplification at $95^{\circ}$ for $10 \mathrm{sec}, 60^{\circ} \mathrm{C}$ for $10 \mathrm{sec}$ and $72^{\circ} \mathrm{C}$ for $5 \mathrm{sec}$. Finally, cooling to $40^{\circ} \mathrm{C}$ for $30 \mathrm{sec}$. 